\title{
Physical activity among nursing students
} Aktywność fizyczna wśród studentów pielęgniarstwa

\section{Leona Cilar, Nina Preložnik, Gregor Štiglic, Dominika Vrbnjak, Majda Pajnkihar}

\author{
Faculty of Health Sciences, University of Maribor \\ CORRESPONDING AUTHOR/AUTOR DO KORESPONDENCJI: \\ Gregor Stiglic \\ Faculty of Health Sciences, University of Maribor \\ Zitna ulica 15, 2000 Maribor, Slovenia \\ tel. (+386) 23004731 \\ e-mail: gregor.stiglic@um.si
}

STRESZCZENIE

Słowa kluczowe:

ABSTRACT

Key words:

\section{AKTYWNOŚC FIZYCZNA WŚRÓD STUDENTÓW PIELĘ̇CNIARSTWA}

Wprowadzenie. Pielęgniarki powinny zachęcać swoich pacjentów do prowadzenia zdrowego trybu życia, ponieważ już w czasie studiów stają się one świadome tego, jak ważna jest aktywność fizyczna. Przedmiotem pracy było zbadanie poziomu aktywności fizycznej studentów pielęgniarstwa.

Cel pracy. Celem pracy było przeanalizowanie stanu aktywności fizycznej studentów pielęgniarstwa oraz poznanie głównych przyczyn w przypadku braku takiej aktywności.

Materiał i metodyka. Przeprowadzono badanie przekrojowe z użyciem mieszanych metod badawczych. Dane ilościowe zostały zebrane za pomocą ankiety w wygodnej próbie 123 studentów, a do ich analizy zastosowano statystykę opisową i dedukcyjną. W przypadku danych jakościowych użyto teorii ugruntowanej z częściowo ustrukturyzowanymi wywiadami z czworgiem celowo dobranych studentów.

Wyniki i wnioski. W części ilościowej badania dostrzeżono znacząco wyższy stosunek aktywności fizycznej uprawianej na zewnątrz do aktywności uprawianej wewnątrz ( $p<0,001$ ). Część jakościowa badania zawiera główną kategorię aktywności fizycznej oraz trzy podkategorie: stosunek do aktywności fizycznej, przeszkody i bodźce zachęcające. Studenci pielęgniarstwa nie uprawiają regularnie aktywności fizycznych z powodów, takich jak braku czasu, obowiązki na uczelni, pora roku czy finanse.

aktywność fizyczna, studenci pielęgniarstwa, dobrostan psychiczny, dobrostan fizyczny

\section{PHYSICAL ACIIVIIY AMONG NURSING STUDENIS}

Introduction. Nurses need to encourage patients to lead a healthy lifestyle, hence it is important that as nursing students they are already aware of the importance of physical activity. The purpose of the study was to investigate the physical activities of nursing students.

Aim. The aim of the study was to find out in what state physical activity of nursing students is and to find out what are their main reasons for lack of physical activity.

Material and methods. We conducted a cross-sectional observational study using a mixed methods design. The quantitative data was collected using the survey method with a convenience sample of 123 students and used descriptive and inferential statistics for the analysis. For the qualitative data we used a Grounded Theory Method with semi-structured interviews on purposive samples of four students.

Results and conclusions. In the quantitative part of this study we found a significantly higher proportion of outdoor physical activity in comparison to indoor physical activity $(p<0.001)$. The qualitative part contains the main categories of physical activity implementation, as well as three sub-categories: attitude to physical activity, barriers and incentives. Nursing students do not do physical activities regularly due to lack of time, obligations at the university, time of the year and finances.

physical activity, nursing students, mental well-being, physical well-being 


\section{INTRODUCTION}

Reduced physical activity is one of the major factors affecting health and is a serious global problem [1]. Nurses play an important role in maintaining people's health and therefore in raising among people awareness of the importance of a healthy lifestyle [2] and also in promoting healthy living among children in kindergartens and schools [3]. It is established that nurses who are physically active and live a healthy life encourage patients more directly and advise them on healthy lifestyles [2]. However, the implementation of physical activity by nurses is largely influenced by their working hours. Nurses having fixed working hours are more physically active in comparison to nurses who have shift work [4].

It is important to familiarize nursing students with healthy living because habits adopted when young are more often maintained throughout life [1]. Besides, it is expected that health care students also represent an example of a healthy lifestyle to be followed by others [5].

In studies conducted in Brazil the researchers found a very low level of physical activity among nursing students $[1,6]$. In Thailand, one third of the students did not do physical activities regularly [5]. A study in Hong Kong showed higher physical activity in male nursing students compared to female nursing students [7], while a study from the US showed full-time nursing students to be more physically active than part-time nursing students [8]. Nursing students in the UK did not meet the recommended physical activity guidelines of the WHO (World Health Organization) [9]. The main obstacles for nursing students to carry out physical activity are lack of free time, physical effort, lack of energy, busy work schedule, mental effort and busy learning schedule $[7,8]$. In a survey carried out in Slovenia between 2011 and 2013 among nursing students, the authors showed reduced physical activity compared to students in other faculties [10].

Reduced physical activity causes poor health in students and increases risk of stress, cardiovascular disease, hypertension, early death, sleep disorders, and obesity [11]. The studies also show a connection between physical and mental health. Reduced physical activity also affects the mental state and the emergence of mental disorders such as depression and anxiety [9].

Physical activity is one of the components of a healthy lifestyle and it is important that nursing students are aware of this as their task is to promote healthy living. It is important to regularly investigate the level of physical activity among nursing students and discover what are the most frequent causes of physical (in)activity.

\section{AIM}

The aim of this study was to determine the level of physical activity among nursing students in one of the higher education institutions in Slovenia and to explore the potential barriers and incentives that stimulate physical activity. In doing so, we set two hypotheses and two research questions.

\section{Hypotheses:}

- H1: The majority of nursing students carry out physical activity (for at least 30 minutes) less than 5 times a week.

- H2: Nursing students often carry out physical activities outdoors, and less in various sports centres.

\section{Research questions:}

- R1: How do nursing students perceive physical activity?

- R2: What are the barriers and incentives for nursing students to carry out physical activity?

\section{MATERIALS AND METHODS}

We conducted a cross-sectional observational study, using the explanatory plan of mixed methods research. Mixed methods research involves the collection of quantitative and qualitative data, using different techniques of quantitative and qualitative analysis and using different techniques and strategies for integrating the results [12]. In the quantitative methodology part, we studied the frequency of physical activity of nursing students and where they carry out this activity, i.e. outdoors or in sports centres. In the qualitative methodology part, we studied how nursing students perceive physical activity, what are the barriers to improve physical activity and factors that encourage them to implement physical activity. To carry out this research, we obtained permission from the institutional Ethics Commission.

\section{Questionnaire}

In the quantitative part we collected the data, using the survey method. We used a questionnaire about physical activity ('Physical activity questionnaire', PAQ) [11]. The questionnaire is divided into three segments. The first segment is referred to domestic activities and consists of the sub-units getting up and preparing for sleep, errands that do not relate to the place of study, watching TV, walking up and down the stairs at home and activities in and around the house. Other segments relate to activities at the place of work and consist of the type of occupation, level of activity at work and transport to and from work. The questionnaire was adapted for our study. As the object of our study was student population, we exchanged the service segment with the educational institution and all the sub-units were adapted and structured to the place of study. The third part is about recreation and consists of the frequency of physical activity during the past 12 months. In the last table of the questionnaire, we added a choice of places where physical activity was carried out (outdoors or in sports centres). We also adjusted the frequency of weekly physical activity implementation, removing activities that are not typical for our area.

In the qualitative part the data was collected using semi-structured interviews in which sets of questions were used for the interviews. Those questions were prepared based on the theory of health promotion [13]. The guideline for the interview contained six questions. The questions in the first part concerned the obstacles why nursing students are not physically active, and the second part, any incentives for physical activity. We used qualitative data analysis method. 


\section{Description of the sample}

In the quantitative part of the study we used convenience sampling. In the survey we included different nursing students with various demographic characteristics. We distributed questionnaires among undergraduate and postgraduate, and among full-time and part-time nursing students. Participants were selected for the study on the basis of the literature review, which shows that nursing students are less physically active compared to students from other faculties [10]. We distributed 150 questionnaires and recorded an $80 \%$ response rate $(n=123)$.

In the qualitative part of the study we selected a dedicated sample in which participants can share experience and form the basis for the sampling method of grounded theory method $[14,15]$. The sample included four nursing students. The entry requirement was physical inactivity of a student, which was determined by the pre-interview question: „Do you know and follow the recommended guidelines of the WHO, which dictate at least 30 minutes of physical activity five times a week?" [16]. When the answer was negative, the interviewee was included in the sample for the interview.

\section{Implementation and data processing}

To carry out the research, we obtained permission from the institutional Ethics Commission. Before carrying out the quantitative part of the survey, participants were acquainted with the facts of anonymity and voluntary participation in the survey. The quantitative part of the research started with a literature review and selection of a validated questionnaire [11]. The questionnaire was translated into Slovene for ease of understanding. Translation was performed by two independent persons (an expert in the field of nursing and an expert in the field of English and Slovene languages). Data were collected in January 2016. Survey questionnaires were distributed to students in writing before the start of lectures or exams. The collected data was analysed using the statistical software IBM SPSS 20.0. We used methods of descriptive statistics, the binomial test and Student's t-test of independent samples.

Before carrying out the qualitative research, interviewees were verbally informed of the progress of the research and their rights. We took into account the principles of the Code of Health Care Ethics in Slovenia [17] and the principle of anonymity, confidentiality, the right to withdraw from participation in the study and accuracy of the data. Chosen interviewees, who were previously identified as physically inactive, were included for interview. The interview was filmed with mobile phones. Clips were stored on the computer and later transcribed and coded. The analysis was conducted using the grounded theory method and qualitative data analysis following Corbin \& Strauss [15]. We started the analysis of the data with open coding, in which we identified individual codes. The next stage was axial coding, which is defined as an intense analysis of the categories where the information is combined [18]. Similar codes were pooled and divided into subcategories. In the last stage we formed a main category with relational coding [15].

\section{RESULTS}

\section{The results of the quantitative part}

The study included 93 (76\%) women and 30 (24\%) men. The participants in the study ranged between 19 and 45 years old, mainly between 20 and 23 years $(77 \%$ of all participants). The participants were also asked what means of transport they use, depending on the distance that must be covered (Tab. 1). The increase of car use is visible and correlates with increasing distances and with a lower percentage of walking.

Tab. 1. The use of transport depending on distance.
\begin{tabular}{|l|c|c|c|c|}
\hline $\begin{array}{c}\text { km } / \text { use of } \\
\text { transport }\end{array}$ & walk & bicycle & $\begin{array}{c}\text { public } \\
\text { transport }\end{array}$ & car \\
\hline up to $1 \mathrm{~km}$ & $84 \%$ & $6 \%$ & $3 \%$ & $7 \%$ \\
\hline $1-5 \mathrm{~km}$ & $38 \%$ & $14 \%$ & $10 \%$ & $38 \%$ \\
\hline more than $5 \mathrm{~km}$ & $6 \%$ & $1 \%$ & $18 \%$ & $75 \%$ \\
\hline
\end{tabular}

The participants were also asked about specific activities in the educational institution and how much average time they spent per week on each of them (see Tab. 2). We showed how many hours per week nursing students spend on activities such as sitting, standing moderate work (labs), standing hard work (clinical practice), walking to the educational institution and walking in the clinical environment. The longest time (over 30 hours) is spent on moderate walking during the clinical placement, and the shortest time (15 hours) on sitting.

Tab. 2. Time spent on certain activities weekly.

\begin{tabular}{|l|c|c|c|c|c|}
\hline $\begin{array}{c}\text { weekly hours } \\
\text { / activity }\end{array}$ & sitting & $\begin{array}{c}\text { standing } \\
\text { moderate } \\
\text { work }\end{array}$ & $\begin{array}{c}\text { standing } \\
\text { hard } \\
\text { work }\end{array}$ & $\begin{array}{c}\text { walking in } \\
\text { educational } \\
\text { institution }\end{array}$ & $\begin{array}{c}\text { walking in } \\
\text { the clinical } \\
\text { environment }\end{array}$ \\
\hline up to 15 hours & $24 \%$ & $30 \%$ & $32 \%$ & $85 \%$ & $43 \%$ \\
\hline $\begin{array}{l}15-30 \text { hours } \\
\text { more than } \\
\text { 30 hours }\end{array}$ & $39 \%$ & $30 \%$ & $16 \%$ & $7 \%$ & $16 \%$ \\
\hline
\end{tabular}

The participants were also asked how they travel from home to the educational institution (Tab. 3). As many as $30 \%$ of participants always go to the educational institution by car but only $38 \%$ never use the car. Half of the participants never walk to the educational institution, but $35 \%$ of them always walk there. The largest percentage $(82 \%)$ never use a bicycle.

Tab. 3. Transport to educational institution.

\begin{tabular}{|l|c|c|c|c|}
\hline & always & often & occasionally & $\begin{array}{c}\text { never } \\
\text { or rarely }\end{array}$ \\
\hline by car & $30 \%$ & $10 \%$ & $20 \%$ & $38 \%$ \\
\hline by public transport & $15 \%$ & $16 \%$ & $16 \%$ & $51 \%$ \\
\hline by bicycle & $1 \%$ & $8 \%$ & $8 \%$ & $82 \%$ \\
\hline walking & $35 \%$ & $10 \%$ & $4 \%$ & $50 \%$ \\
\hline
\end{tabular}


In the third part of the questionnaire we asked the participants where each activity is carried out (outdoors or in sports centres) and what amount of time they spent on implementing those activities. From participants who replied to be physically active 5-7 times per week, we wanted to know the length of time (in hours) they spent on physical activity, as we were also interested in knowledge of where this activity takes place (outdoors or in sports centres).

We found that only 33 (26\%) participants carry out physical activity at least 5 times a week, as recommended by WHO guidelines. Most participants (74\%) do not perform any physical activity more than 5 times per week $(p<0.001)$. In assessing the amount of time they spend outdoors or in sports centres, students are more often $(\mathrm{p}<0.001)$ outdoors $(\mathrm{M}=10.89)$ than in sports centres $(\mathrm{M}=2.18)$.

\section{Results of the qualitative part}

We identified the main category of implementing physical activity to be associated with three sub-categories: attitude to physical activity, barriers and stimulations. Tab. 4 shows the main category, sub-categories and the associated codes.

Tab. 4. Main category, sub-categories and codes.

\begin{tabular}{|c|c|c|}
\hline $\begin{array}{c}\text { Main } \\
\text { category }\end{array}$ & Sub-categories & Codes \\
\hline \multirow{4}{*}{$\begin{array}{l}\text { Physical } \\
\text { activity }\end{array}$} & $\begin{array}{c}\text { Attitude towards } \\
\text { physical activity }\end{array}$ & $\begin{array}{c}\text { Physical activity outdoors, physical activity } \\
\text { in sports centre, general well-being, influence } \\
\text { on physiological processes in the body. }\end{array}$ \\
\cline { 2 - 3 } & Barriers & $\begin{array}{r}\text { Time, duties, finance, motivation, } \\
\text { time of the year, way of thinking. }\end{array}$ \\
\cline { 2 - 3 } & Stimulations & Social, personal, well-being, free time. \\
\hline
\end{tabular}

\section{Attitude towards physical activity}

The sub-category attitudes towards physical activity refers to the views and attitudes of the participants towards physical activity. The corresponding codes are: outdoor physical activity, sports centre physical activity, general well-being and the influence on physiological processes on the body. Some physical activities are understood as outdoor activities while others as doing physical activities in a sports centre. Participants may understand physical activity as both.

“...to go, maybe on a long walk, to go running for recreation, for example in a forest or on the street," and "...also in some fitness centre, using different exercises that are available, like running on the track, weightlifting..." (Interviewee 1)

Physical activity as influence on general well-being.

"...I think that it's important for the general well-being of individuals to maintain good health." (Interviewee 2).

"...contribute to better well-being, a good mood, beautiful skin and certainly to raising self-esteem." (Interviewee 3).

Movement affects physiological processes in the body.

“....we release more adrenaline, our heart rate increases, we sweat more. Muscles are more overloaded and therefore form a better shape." (Interviewee 3).

\section{Barriers}

The participants listed many reasons why they are physically inactive. The most common are: time, duties, finance, motivation and the time of the year. The lack of time is one of the most common problems among the three interviewees.

"... (uhm) maybe thinking, that there is not enough time, considering that I work in that kind of profession,..." (Interviewee 1).

"I'm not physically active because I don't have enough time because of also caring for my children..." (Interviewee 3).

Interviewees are prevented for various reasons, such as work, educational institution and home.

"For example, the nature of work is such that you are exhausted when you come home." (Interviewee 1).

"...uhm, yes the most common problem is the educational institution..." (Interviewee 2).

"...because of caring for my children, looking after the household..." (Interviewee 3).

They present finance as a major problem, such as expensive programs in the fitness centre.

"....so I just loose the will to exercise and maybe it was also financial problems with it." (Interviewees 1).

"Also finance is a problem nowadays, because I can hardly afford activities that I like and that are also financially acceptable." (Interviewee 3 ).

All interviewees mentioned a lack of motivation.

“...that I don't exercise alone, when I am in company I am more encouraged." (Interviewee 1).

"...the will to exercise is necessary and helps." (Interviewee 2).

The next barrier is influence of the time of the year (season) on physical activity.

"...then you don't do it, or in winter it is dark earlier outside, that's the main reason..." (Interviewee 2).

"... when its weather is good then you have a chance to exercise for free..." (Interviewee).

A big influence is also how each individual thinks.

"And my way of thinking is that I just don't take time and force myself..." (Interviewee 1) "...or I don't know, I have something else to do at the same time or I just make an excuse, so you don't have to..." (Interviewee 2).

\section{Stimulations}

The interviewees suggested certain factors that would encourage them to implement physical activity. Social stimulation would mean a lot for interviewees.

“....yes, the recommendation of friends or co-workers to physical activity..." (Interviewees 1).

"...not having to do the household, and an understanding family..." (Interviewee 3).

Personal stimulation represents satisfaction and self-esteem to interviewees.

“...to feel better afterwards." (Interviewee 2).

“...certainly for raising self-esteem...” (Interviewee 3).

It stimulates them finding that after physical activity they feel better.

"...for the general well-being of individuals and keeping well." (Interviewee 2).

"It helps to feel better and healthier..." (Interviewee 3). 
They list more free time as a stimulus.

"Yes, maybe it would stimulate me if... I had more free time..." (Interviewee 4).

\section{DISCUSSION}

We wanted to find out if nursing students are enough physically active, based on WHO guidelines. Therefore, we set the hypothesis that most of nursing students carry out physical activity for less than five times a week. The hypothesis was confirmed, as only 33 participants (26\%) carry out physical activity more than five times a week $(\mathrm{p}<0.001)$. We were also interested where the students prefer to carry out physical activity, how many times a week they do so, and how much physical activity is part of their lifestyle.

We found that the choice of transport to their educational institution depends on the distance. Most students come to the educational institution regularly by car, many of them walk there, but a suprisingly low percentage use a bicycle. Irrespective to the number of kilometers to go, less than one third of students choose to use a bicycle. That is suprising, considering that there are many programmes that promote usage of bicycles in public and that there are many bicycles available to use. Chosing the car as a way of transport to the educational institution for a distances of 1 to 5 kilometers could be connected to barriers, which we listed in the qualitative part of the research, such as time, duties, the time of year, ways of thinking, motivation, inconsistent and busy work schedule.

We also asked about the type of physical activity when being in the educational institution and found that students spend much of the time sitting, however additionally, depending on the profession, many of them do standing moderate work (when in the labs), standing hard work (clinical environment) and a lot of walking (mostly between institutions). The time of uninterrupted sitting can lead to developing different chronic non-communicable diseases and other disorders connected with health [19]. It can also influece the general mortality due to cardiovascular diseases. Longer uninterrupted sitting also influences people who otherwise respect recommendations for physical activity. Our recommendations would be to take more frequent breaks for walks and stimulate students to use stairs rather than elevators. Inconsistent and busy work schedule and exposure to stress present big barriers to nursing students for implementing physical activities [11], what can have a big impact on working hours at work and in educational institution.

The Student t-test shows that most participants prefer to do physical activities outside rather than in sports centres $(\mathrm{p}<0.001)$. This is connected with our findings in the qualitative part of the research, where we found that weather and seasons influence physical activity. Bad weather discourage students from being physically active, because they cannot go outside. When selecting the type of physical activity, we should consider the ability to persue it outdoors and at low costs.

We found out, that nursing students envisage different physical activitiy. Some of them percieve physical activity as outdoor activities in the fresh air, and others as activities in sports centers.

They also think that physical activity has a big impact on physiological processes in the body. The research found that effects on physiological processes influence improving cognitive function [11]. Some authors have found that physically active students have better physical health than those who are not active [5]. Physically active health workers who promote good health have opportunities to lower health costs in the future [20].

Studies in the USA, Brazil and in the Great Britain show extremely low levels of physical activity among nursing students $[11,1,9]$, with similar findings in Slovenia [10]. This led us to decide that the research will include students who are the least physically active and who can give us the main reasons for physical inactivity. They mentioned lack of time, different duties (educational institutions, work, and families), finance and their way of thinking. Additional barriers among nursing students are academic obligations, family and work obligations [8]. Our findings are similar to other authors [7] that the biggest barriers for students are work, poor social support, finance, lack of energy, health, and lack of free time. They suggest solutions regarding the time management; nursing students must learn how to organize their time. We could set up sports teams within the educational institution, which would supply company and social support. The big influence on physical activity among interviewees have also the seasons and weather. Participants see winter and bad weather as major barriers for doing any physical activities. Students' possible stimulations are more free time, social support from friends, co-workers and family, and advertising on television. They also mentioned that they would implement physical activity if there were enough personal motivational factors, such as pleasure and well-being.

We need to be aware of certain limitations imposed by this research. The sample in the qualitative research was small, including just four interviewees, hence the findings cannot be generalized to the entire nursing population. The research was carried out in only one institution and we cannot know what kind of beliefs nursing students in other institutions hold. Other researchers conclude that first year nursing students are less physically active than students in higher years [5]. It may be interesting to find out the differences between Slovenian nursing students generally.

We note that the results in our sample coincide with the findings in other studies. Nursing students in other studies indicate similar barriers to carry out physical activity and lack stimulation to incrase physical activity. Universities and clinical institutions should give more thought to incentives for physical activity among students, such as having fitness centers, football fields and other amenities. They should also provide healthy meals [5]. The education system should also give attention to awareness among nursing students on becoming physically active and maintaining good body condition [8]. It is very important to find out what are the factors that are associated with the habits of students and also change approaches of health promotion among nursing students [11]. 


\section{CONCLUSIONS}

Regular physical activity is very important for general well-being of individuals. We can implement physical activity outdoors or in sports centres. Nursing students are aware of the need for regular physical activity, but despite that, they do not follow the guidelines recommended by the WHO. Reasons differ, such as: lack of time, too many duties, time of the year and lack of finance. Physical inactivity is also affected by individuals' way of thinking and lack of motivation. Students who are not physically active realise that they need to take time for physical activities and they mentioned some stimulations such as: social and personal well-being or time. The influence of friends and family on implementation of physical activity plays a large part.

It is important that nursing students are aware of the importance of regular physical activity. It would be possible to achieve this by introducing corresponding education in study programs so long as it is seen as an object that is estimated and is a prerequisite for the whole class, otherwise it might represent an additional burden and could dissuade students from physical activity altogether. Above all, we believe that it is necessary to introduce physical activity outdoors, as we found out that a large percentage of students prefer to be active outdoors rather than in sports centres. It is important to motivate the entire families and communities to implement group trainings, as we have found that physical activity in company represents a bigger influence for those who are physically inactive. It is also important to introduce more stable schedules in which students can create a daily routine that can include physical activity. It is essential to do more research in this area in order to achieve reliable results. Analysing existing literature and researching work opened other questions, such as whether enough importance is given to promotion of physical activity among nursing students and whether educational institutions encourage students to implement physical activity.

\section{REFERENCES}

1. da Silva Pires CG, Carneiro Mussi F, Borges de Cerqueira B, et al. Physical activity practice among undergraduate students in nursing. Acta Paul Enferm. 2013; 26(5): 436-443.

2. Esposito EM, Fitzpatrick JJ. Registered nurses' beliefs of the benefits of exercise, their exercise behaviour and their patient teaching regarding exercise. International J Nurs Pract. 2011; 17(4): 351-356.

3. Banfield M, McGorm K, Sargent G. Health promotion in schools: A multi-method evaluation of an Australian School Youth Health Nurse Program. BMC Nurs. 2015; 21(14): 1-11.

4. Škrbina V, Zurc J. Gibalna aktivnost pri diplomiranih medicinskih sestrah, ki opravljajo enoizmensko in večizmensko delo. Obzor Zdrav Neg. 2016; 50(3): 193206.

5. Klainin-Yobas P, He HG, Lau Y. Physical fitness, health behaviour and health among nursing students: A descriptive correlational study. Nurse Educ Today. 2015; 35(12): 1-7.

6. Monteiro CR, Mancussi e Faro AC. Physical exercise according to nursing students' perceptions. Lat Am Enfermagem. 2006; 14(6): 843-848.

7. Chung-Yan Chan J. Psychological determinants of exercise behavior of nursing students. Contemp Nurse. 2014; 49(1): 60-67.

8. Bryer J, Cherkis F, Raman J. Health-Promotion Behaviors of Undergraduate nursing Students: A Survey Analysis. Nurs Educ Perspect. 2013; 34(6): 410-415.

9. Hawker CL. Physical activity and mental well-being in student nurses. Nurse Educ Today. 2012; 32(3): 325-331.

10. Babić M, Sitar P, Radmilovič PH, et al. Predlogi aktivnosti za zdravo in varno delovno in bivalno okolje za študente in zaposlene na UM (TDOUM 2014-2020). Maribor: Univerza v Mariboru Center za razvoj kakovosti; 2014.

11. Zanotti FitzGerald L. Categorization and determinants of physical activity among nursing students. J Nurs Educ Pract. 2015; 5(5): 10-20.

12. Vrbnjak D, Pajnkihar M. Raziskave mešanih metod v zdravstveni negi. [in:] Pajnkiha $M$, ed. Znanstveni dokazi za razvoj izobraževanja in prakse v zdravstvu. Mednarodna konferenca, 2. junij 2015. Maribor. Maribor: Fakulteta za zdravstvene vede; 2015. s. 30-33.

13. Pender NJ. The Health Promotion Model. Manual. United States of America: Deep Blue; 2011.

14. Ellis P. Understanding Research for Nursing Students. California: SAGE Publications; 2012.

15. Corbin J, Strauss A. Basics of Qualitative Research. California: SAGE Publications; 2015.

16. World Health Organization. Global Recommendations on Physical Acivity for Health. Geneva: World Health Organization; 2010.

17. Code of Ethics in Health Care and supply of Slovenia. Official Journal of the Republic of Slovenia no. 52; 2014.

18. Corbin J, Strauss A. Basics of Qualitative Research. California: SAGE Publications; 1998.

19. Maučec Zakotnik J, et al. Z gibanjem do zdravja. Ljubljana: National institute for public health; 2016.

20. Hosseini M, Ashktorab T, Hossein Taghdisi M, et al. Health-Promoting Behaviors and Their Association With Certain Demographic Characteristics of Nursing Students of Tehran City in 2013. Glob J Health Sci. 2015; 7(2): 264-272.

Manuscript received: 09.02.2017

Manuscript accepted: 13.03.2017 